\title{
PHYSIOLOGICAL RESPONSES OF PEANUT CROPS TO IRRIGATION WITH BRACKISH WATERS AND APPLICATION OF ORGANO-MINERAL FERTILIZERS $^{1}$
}

\author{
JOSÉ THOMAS MACHADO DE SOUSA ${ }^{2 *}$, GEOCLEBER GOMES DE SOUSA ${ }^{3}$, ELANE BEZERRA DA SILVA ${ }^{4}$, \\ FRANCISCO BARROSO DA SILVA JUNIOR ${ }^{4}$, THALES VINÍCIUS DE ARAÚJO VIANA ${ }^{2}$
}

\begin{abstract}
The use of organo-mineral fertilizer is an alternative measure to mitigate salt stress in semiarid regions. Thus, the objective of this work was to evaluate the physiological indexes of peanut crops under irrigations with fresh and brackish waters and applications of organo-mineral fertilizers. The experiment was conducted from June to September, 2019, at the Universidade da Integração Internacional da Lusofonia AfroBrasileira (UNILAB), in Redenção, state of Ceará, Brazil, using a completely randomized experimental design in a $5 \times 2$ factorial arrangement, with four replications. The treatments consisted of five soil fertilizers (F1= $100 \%$ NPK mineral fertilizer at the recommended rate; F2 $=100 \%$ bovine manure-based biofertilizer; F3= $100 \%$ plant ash; F4 $50 \%$ mineral fertilizer and 50\% bovine manure-based biofertilizer; and $\mathrm{F} 5=50 \%$ mineral fertilizer and 50\% plant ash); and two salinity levels (electrical conductivities) of the irrigation water (1.0 and $5.0 \mathrm{dS} \mathrm{m} \mathrm{m}^{-1}$ ). Photosynthetic rate, transpiration, stomatal conductance, leaf temperature, internal $\mathrm{CO}_{2}$ concentration, water use efficiency, and chlorophyll index of the plants were evaluated at 40 and 54 days after sowing (DAS). Plants irrigated with fresh water presented higher stomatal conductance, photosynthetic rate, and transpiration, regardless of the fertilizer used. The use of $100 \%$ bovine manure-based biofertilizer resulted in decreases in salt stress and increases in water use efficiency at 40 DAS, and decreases in leaf temperature and increases in relative chlorophyll content at 54 DAS.
\end{abstract}

Keywords: Arachis hypogaea L. Salinity. Organic fertilizer. NPK.

\section{RESPOSTAS FISIOLÓGICAS NA CULTURA DO AMENDOIM IRRIGADO COM ÁGUAS SALINAS E FERTILIZAÇÃO ORGANOMINERAL}

RESUMO - A adubação organomineral é uma alternativa para mitigar o estresse salino em regiões semiáridas. Baseado nisso, objetivou-se avaliar a adubação organomineral sob os índices físiológicos na cultura do amendoim irrigado com água de baixa e alta salinidade. $\mathrm{O}$ experimento foi realizado no período de junho a setembro de 2019, na Universidade da Integração Internacional da Lusofonia Afro-Brasileira (UNILAB), no município de Redenção, Ceará, em delineamento experimental inteiramente casualizado, fazendo uso do esquema fatorial $5 \times 2$, com quatro repetições. Os tratamentos consistiram em cinco fertilizantes de solo $(\mathrm{F} 1=$ $100 \%$ fertilizante mineral NPK na taxa recomendada; $\mathrm{F} 2=100 \%$ biofertilizante à base de esterco bovino; $\mathrm{F} 3=$ $100 \%$ cinza vegetal; $\mathrm{F} 4=50 \%$ fertilizante mineral e $50 \%$ biofertilizante à base de esterco bovino; e $\mathrm{F} 5=50 \%$ fertilizante mineral e $50 \%$ de cinzas de plantas); e dois níveis de salinidade (condutividade elétrica) da água de irrigação $\left(1,0\right.$ e $\left.5,0 \mathrm{dS} \mathrm{m}^{-1}\right)$. A taxa fotossintética, a transpiração, a condutância estomática, a temperatura foliar, a concentração interna de $\mathrm{CO}_{2}$, a eficiência do uso da água e o índice de clorofila das plantas foram avaliados aos 40 e 54 dias após a semeadura (DAS). Plantas irrigadas com água de baixa salinidade proporcionaram maiores valores de condutância estomática, taxa fotossintética e transpiração, independentemente do método de fertilização adotado. A adubação com biofertilizante bovino $100 \%$ atenua o estresse salino e aumenta a eficiência no uso da água aos 40 DAS, além de mitigar a temperatura foliar e favorecer o maior teor relativo de clorofila aos 54 DAS.

Palavras-chave: Arachis hypogaea L. Salinidade. Insumo orgânico. NPK.

\footnotetext{
${ }^{*}$ Corresponding author

${ }^{1}$ Received for publication in $06 / 02 / 2020$; accepted in $04 / 29 / 2021$.

Paper extracted from the monograph of the first author.

${ }^{2}$ Department of Agricultural Engineering, Universidade Federal do Ceará, Fortaleza, CE, Brazil; thssousa2015@gmail.com - ORCID: 0000 -0001-9460-1461, thales@ufc.br-ORCID: 0000-0003-0722-6371.

${ }^{3}$ Rural Development Institute, Universidade da Integração Internacional da Lusofonia Afro-Brasielira, Redenção, CE, Brazil; sousagg@unilab.edu.br-ORCID: 0000-0002-1466-6458.

${ }^{4}$ Department of Soil Sciences, Universidade Federal do Ceará, Fortaleza, CE, Brazil; elanebdsilva@live.com - ORCID: 0000-0002-32247791,juniorbarroso_99@hotmail.com-ORCID: 0000-0001-9203-3886.
} 


\section{INTRODUCTION}

Peanut (Arachis hypogaea L., Fabaceae) is one of the main crops in Brazil and in other parts of the world, whose grains are consumed fresh or as processed products. These grains are an important source of plant protein and edible oil, which increases the economic interest for this crop (BARBOSA; HOMEM; TARSITANO, 2014).

Peanut crops in arid and semiarid regions of Brazil require irrigation due to the low rainfall indexes and poor rainfall spatial and temporal distributions, denoting the need for researches for new strategies (CARVALHO et al., 2020). The use of brackish water in agriculture is an important alternative to fresh water due to the scarcity of this natural resource in some regions; however, the frequent use of these waters combined with arid climate conditions increases salt accumulation on the soil surface (MINHAS et al., 2020; RODRIGUES et al., 2020).

Salt stress can reduce the soil osmotic potential causing water imbalance due to accumulation of toxic ions and, consequently, physiological imbalances due to ion accumulations $\left(\mathrm{Na}^{+}\right.$and $\left.\mathrm{Cl}^{-}\right)$in the chloroplasts, which affect biochemical and photochemical processes involved in photosynthesis and nutritional balance of plants (FREIRE et al., 2013; TAIZ et al., 2017).

According to Albuquerque, Santos, and Fonsêca (2018), organo-mineral fertilizer applications is an efficient alternative measure to minimize negative effects of salinity to soils. However, the interaction between salts and mineral and organic fertilizers is complex due to interactions of salts in the irrigation water and the different sources and concentrations of soil chemical and organic fertilizers. When this agricultural practice is used adequately, it assists in increasing plant growth and yield (SOUZA et al., 2018; SOUSA et al., 2018).

Thus, the objective of this work was to evaluate the physiological indexes of peanut crops under irrigations with fresh and brackish waters and applications of organo-mineral fertilizers.

\section{MATERIAL AND METHODS}

The experiment was conducted from June to September, 2019, at the experimental area of the Seedlings Production Unity (UPMA) of the Universidade da Integração Internacional da Lusofonia Afro-Brasileira (UNILAB), Auroras campus, in Redenção, state of Ceará, Brazil. The region presents an Aw', tropical rainy, very hot, with rainfall predominating in the summer and autumn, according to climate classification of Köppen (1923).

A completely randomized experimental design was used in a $5 \times 2$ factorial arrangement, with four replications. The treatments consisted of five different soil fertilizers $(\mathrm{F} 1=100 \%$ NPK mineral fertilizer at the recommended rate; F2 $=100 \%$ bovine manure-based biofertilizer; F3 $=100 \%$ plant ash; F4 $=50 \%$ mineral fertilizer and $50 \%$ bovine manure-based biofertilizer; and F5 $=50 \%$ mineral fertilizer and $50 \%$ plant ash); and two salinity levels (electrical conductivities) of the irrigation water (1.0 and $5.0 \mathrm{dS} \mathrm{m}^{-1}$ ).

The substrate used for the plants was obtained from a mixture of aloof, sand, and manure bovine at the proportion of $4: 3: 1$, respectively. The chemical composition of the substrate is shown in Table 1.

Table 1. Chemical attributes of the substrate used before the application of the treatments.

\begin{tabular}{cccccccccc}
\hline \multicolumn{10}{c}{ Chemical attributes } \\
\hline $\mathrm{OM}$ & $\mathrm{N}$ & $\mathrm{P}$ & $\mathrm{K}$ & $\mathrm{Mg}$ & $\mathrm{Ca}$ & $\mathrm{Na}$ & $\mathrm{pH}$ & $\mathrm{ESP}$ & EC \\
\hline $\mathrm{g} \mathrm{kg}^{-1}$ & $\mathrm{~g} \mathrm{~kg}^{-1}$ & $\mathrm{mg} \mathrm{Kg}^{-1}$ & $\mathrm{~g} \mathrm{~kg}^{-1}$ & & $\mathrm{cmol}_{\mathrm{c}} \mathrm{dm}^{-3}$ & & & $\%$ & $\mathrm{dS} \mathrm{m}^{-1}$ \\
\hline 4.34 & 0.26 & 65 & 0.25 & 1.1 & 1.2 & 0.33 & 6.2 & 7 & 1.19 \\
\hline
\end{tabular}

$\mathrm{OM}=$ organic matter; $\mathrm{ESP}=$ exchangeable sodium percentage $; \mathrm{EC}=$ electrical conductivity .

Seeds of the BR-1 peanut cultivar were sown to a depth of $2 \mathrm{~cm}$ in 8 -liter polyethylene pots, using 5 seeds per pot. The plants were thinned at 10 days after sowing (DAS), leaving only the most vigorous plant.

The saline solutions were prepared using $\mathrm{NaCl}, \mathrm{CaCl}_{2} \mathrm{H}_{2} \mathrm{O}$, and $\mathrm{MgCl}_{2} 6 \mathrm{H}_{2} \mathrm{O}$; the desired electrical conductivities (EC) were achieved using the proportion of $7: 2: 1$, respectively, considering the correlation between EC and salt concentration $\left(\right.$ mmolc $\left.\mathrm{L}^{-1}=\mathrm{EC} \times 10\right)(\mathrm{RHOADES} ; \mathrm{KANDIAH}$; MASHALI, 2000). Daily irrigation with brackish water started at 12 DAS; the volume was calculated according to the drainage lysimeter method (BERNARDO et al., 2019), maintaining the soil at the field capacity.

The bovine manure-based biofertilizer was prepared using fresh bovine manure and water at the proportion of $1: 1$. This mixture was stored in 100liter plastic pots for aerobic fermentation for 30 days. 
The plant ash used was acquired from burn of sugarcane plants in a farm in Redenção, Ceará, Brazil. The results of the chemical analyses of the soil organic fertilizers are shown in Table 2.

The amount of soil fertilizer required for the peanut plants was based on the amount of nutrients in the substrate (Table 1) and maximum recommended rates of chemical fertilizers described by Fernandes (1993): $15 \mathrm{~kg} \mathrm{ha}^{-1}$ of N, $62.5 \mathrm{~kg} \mathrm{ha}^{-1}$ of $\mathrm{P}_{2} \mathrm{O}_{5}$, and $50 \mathrm{~kg} \mathrm{ha}^{-1}$ of $\mathrm{K}_{2} \mathrm{O}$. Considering a stand of
10.000 plants $\mathrm{ha}^{-1}$, the maximum estimated rate per plant was $1.8 \mathrm{~g}$ of $\mathrm{N}, 7.5 \mathrm{~g}$ of $\mathrm{P}_{2} \mathrm{O}_{5}$, and $6.0 \mathrm{~g}$ of $\mathrm{K}_{2} \mathrm{O}$.

The nutrients in the substrate were estimated by multiplying the substrate density $\left(1.3 \mathrm{~g} \mathrm{dm}^{-3}\right)$ by the substrate volume in each pot $(8 \mathrm{~L})$ and, then, multiplying this value $\left(10.4 \mathrm{~kg}\right.$ plant $\left.^{-1}\right)$ by the quantities of $\mathrm{N}, \mathrm{P}$, and $\mathrm{K}$ shown in the substrate analysis (Table 3 ).

Table 2. Essential macro and micronutrients in the bovine manure-based biofertilizer and plant ash used.

\begin{tabular}{|c|c|c|c|c|c|c|c|c|c|}
\hline \multicolumn{10}{|c|}{ Chemical attributes } \\
\hline \multirow{2}{*}{ Organic fertilizers } & $\mathrm{N}$ & $\mathrm{P}$ & $\mathrm{K}$ & $\mathrm{Ca}$ & $\mathrm{Mg}$ & $\mathrm{Fe}$ & $\mathrm{Cu}$ & $\mathrm{Zn}$ & $\mathrm{Cu}$ \\
\hline & & & $\mathrm{g} \mathrm{L}^{-1}$ & & & \multicolumn{4}{|c|}{$\mathrm{mg} \mathrm{L}^{-1}$} \\
\hline Biofertilizer & 0.82 & 1.4 & 1 & 2.5 & 0.75 & 142 & 1.2 & 68 & 14.7 \\
\hline \multirow{2}{*}{ Plant ash } & \multicolumn{5}{|c|}{$\mathrm{g} \mathrm{kg}^{-1}$} & \multicolumn{4}{|c|}{$\mathrm{g} \mathrm{kg}-^{1}$} \\
\hline & 0.4 & 1.13 & 54.4 & 28.7 & 13.9 & 7819 & 10.5 & 38 & 241 \\
\hline
\end{tabular}

Table 3. Estimated supply of nutrients by the substrate, and nutritional supplementation required by the plants.

\begin{tabular}{|c|c|c|c|}
\hline \multicolumn{4}{|c|}{ Estimated supply of nutrients } \\
\hline \multirow{2}{*}{ Chemical attributes } & \multicolumn{3}{|c|}{ Nutrients } \\
\hline & $\mathrm{N}$ & $\mathrm{P}$ & $\mathrm{K}$ \\
\hline Recommendation (g plant ${ }^{-1}$ ) & 1.8 & 7.5 & 6.0 \\
\hline Substrate (g kg-1 $)$ & 0.26 & 0.065 & 0.65 \\
\hline${ }^{\#}$ Total nutrient contribution per pot & 2.70 & 0.67 & 2.6 \\
\hline Supplemental mineral nutrition (g plant $\left.{ }^{-1}\right)$ & 0 & 6.83 & 3.4 \\
\hline \multicolumn{4}{|l|}{ Organic need for complementation } \\
\hline Biofertilizer (g L plant $\left.{ }^{-1}\right)$ & 0 & 5.0 & 0 \\
\hline Plant ash $\left(\mathrm{g} \mathrm{kg}^{-1}\right.$ plant $\left.^{-1}\right)$ & 0 & 1.49 & 0 \\
\hline
\end{tabular}

\#\# = substrate density $\left(1.3 \mathrm{~g} \mathrm{dm}^{-3}\right)$ multiplied by the volume of substrate in each pot.

Considering the estimated nutrient supply (Table 3), weekly manual fertilizer applications started at $8 \mathrm{DAS}$, according to the proportions for each treatment. Thus, $1.8 \mathrm{~g} \mathrm{plant}^{-1} \mathrm{~N}, 6.3 \mathrm{~g} \mathrm{plant}^{-1}$ $\mathrm{P}_{2} \mathrm{O}_{5}$, and 6.0 g plant $^{-1} \mathrm{~K}_{2} \mathrm{O}$ were used for $\mathrm{F} 1$. The organo-mineral fertilizer was applied in F4 and F5 using 0.9 g plant $^{-1}$ of $\mathrm{N}, 3.7 \mathrm{~g} \mathrm{plant}^{-1}$ of $\mathrm{P}_{2} \mathrm{O}_{5}$, and $3.0 \mathrm{~g}$ plant $^{-1}$ of $\mathrm{K}_{2} \mathrm{O}$.

Considering the nutritional supplementation requirements (Table 3) and the quantities of NPK (Table 2), the bovine manure-based biofertilizer was applied using $5.0 \mathrm{~L} \mathrm{plant}^{-1}$ for the rate of $100 \%$ (F2) and $2.5 \mathrm{~L} \mathrm{plant}^{-1}$ for the rate of $50 \%(\mathrm{~F} 4)$. The rates of plant ash applied were $1.5 \mathrm{~kg} \mathrm{plant}^{-1}$ for the rate of
$100 \%(\mathrm{~F} 3)$ and $0.75 \mathrm{~kg} \mathrm{plant}^{-1}$ for the rate of $50 \%$ (F5).

The physiological indexes: photosynthetic rate (A), transpiration (E), stomatal conductance (gs), leaf temperature (LT), and internal CO2 concentration $(\mathrm{Ci})$ were evaluated at 40 and 54 DAS by using an infra-red gas analyzer (Li-6400 XT; LiCor, Lincoln, USA) in an open system with air flow of $300 \mathrm{~mL} \mathrm{~min}^{-1}$. The measurements were done between 8:00 and 10:00 a.m., using fully expanded leaves. These data were used to quantify the water use efficiency (WUE).

The relatively chlorophyll levels were also measured at 40 and 54 DAS, using a non-destructive 
method, with a portable chlorophyll meter (SPAD 502 Plus). The measures were done in the same leaves used to measure the physiological indexes.

The results were subjected to analysis of variance and the means were compared by the Tukey's test at 5\% and $1 \%$ significance level, using the Assistat 7.7 Beta program (SILVA; AZEVEDO, 2016).

\section{RESULTS AND DISCUSSION}

The analyses of variance showed that the interaction between salinity levels and soil organomineral fertilizers were significant for all variables evaluated, except for internal $\mathrm{CO}_{2}$ concentration at 40 and 54 days after sowing (DAS), and chlorophyll index at 40 DAS (Table 4).

Table 4. Analysis of variance for stomatal conductance (gs), photosynthetic rate (A), transpiration (E), internal $\mathrm{CO}_{2}$ concentration (Ci), leaf temperature (LT), water use efficiency (WUE), and chlorophyll index (SPAD) evaluated at 40 and 54 DAS in peanut crops grown in soils subjected to different fertilizer applications and under irrigation with fresh and brackish waters.

\begin{tabular}{|c|c|c|c|c|c|c|c|}
\hline \multirow{2}{*}{\multicolumn{2}{|c|}{ Variation Sources }} & \multicolumn{6}{|c|}{ Mean square } \\
\hline & & \multicolumn{6}{|c|}{40 DAS } \\
\hline & DF & gs & $A$ & $\mathrm{E}$ & $\mathrm{Ci}$ & $\mathrm{LT}$ & WUE \\
\hline Treatments & 9 & $17.83^{* *}$ & $7.66^{* *}$ & $10.41 * *$ & $29.11^{\mathrm{ns}}$ & $92.34 * *$ & $4.58 * *$ \\
\hline Saline levels (SL) & 1 & $115.91 * *$ & $1855^{* *}$ & $64.08 * *$ & $245.09^{\mathrm{ns}}$ & $637.24 * *$ & $15.86^{* *}$ \\
\hline Fertilization $(\mathrm{F})$ & 4 & $3.81 * *$ & $4.65 * *$ & $4.20 * *$ & $1.78^{\mathrm{ns}}$ & $8.72 * *$ & $1.46^{\mathrm{ns}}$ \\
\hline SLxF & 4 & $7.33 * *$ & $7.95^{* *}$ & $3.19 *$ & $2.45^{\mathrm{ns}}$ & $39.74 * *$ & $4.88 * *$ \\
\hline Residue & 30 & 0.004 & 2.57 & 0.07 & 178.26 & 0.09 & 0.43 \\
\hline Total & 39 & & & & & & \\
\hline \multirow[t]{3}{*}{ CV (\%) } & & 32.28 & 19.82 & 16.93 & 5.01 & 1.05 & 12.61 \\
\hline & & \multicolumn{6}{|c|}{$54 \mathrm{DAS}$} \\
\hline & DF & gs & $A$ & $\mathrm{E}$ & $\mathrm{Ci}$ & $\mathrm{LT}$ & WUE \\
\hline Treatments & 9 & $60.25 * *$ & $33.33 * *$ & $24.93 * *$ & $0.99^{\mathrm{ns}}$ & $3.85^{* *}$ & $18.04 * *$ \\
\hline Saline levels (SL) & 1 & $177.23 * *$ & $189.21 * *$ & $65.26^{* *}$ & $0.82^{\mathrm{ns}}$ & $1.25^{\mathrm{ns}}$ & $107.66^{* *}$ \\
\hline Fertilization (F) & 4 & $82.00 * *$ & $20.25 * *$ & $29.76 * *$ & $1.36^{\mathrm{ns}}$ & $5.25 * *$ & $9.26 * *$ \\
\hline SLxF & 4 & $9.23 * *$ & $7.45^{* *}$ & $10.01 * *$ & $0.66^{\mathrm{ns}}$ & $5.25 * *$ & $4.42 * *$ \\
\hline Residue & 30 & 0.0006 & 0.95 & 0.03 & 299.43 & 0.14 & 0.15 \\
\hline Total & 39 & & & & & & \\
\hline CV (\%) & & 9.97 & 11.41 & 7.41 & 5.83 & 1.26 & 11.21 \\
\hline
\end{tabular}

$\mathrm{DF}=$ degrees of freedom, $\mathrm{CV}(\%)=$ coefficient of variation, $\mathrm{DAS}=$ days after sowing. $*=$ significant by the $\mathrm{F}$ test at $5 \%$; $* *=$ significant by the $\mathrm{F}$ test at $1 \% ; \mathrm{ns}=$ not significant.

Stomatal conductance was significantly higher when the plants were irrigated with fresh water at 40 DAS, regardless of the fertilizer applied (Table 5). The low stomatal opening of plants in saline environments is probably a strategy of plants to avoid excessive loss of water to the atmosphere by decreasing the osmotic potential, which hinders water absorption by roots (PRAZARES et al., 2015).

Dias et al. (2017) evaluated physiological indexes of sesame crops grown under salt stress and different nitrate and ammonium proportions and found decreases in stomatal conductance as the water salinity was increased. However, the results found in the present study for plants that received $100 \%$ bovine manure-based biofertilizer or $100 \%$ plant ash were similar to those of Sousa et al. (2018), who found decreases in stomatal conductance in soybean plants as the water salinity was increased, but at a lower intensity than that found when using the organic input.

The stomatal conductance of plants in F1, F3, F4, and F5 was similar at 54 DAS, and statistically higher than F2 when using irrigation with fresh water (Table 5). These fertilizers probably generated a better nutritional balance; moreover, the plant ash in F3 and F5 may have increased $\mathrm{K}^{+}$efficiency, resulting in accumulation of $\mathrm{K}^{+}$in guard-cells and contributing to the water movement inside these cells, which increases the cell turgidity and results in a higher stomatal opening (COSTA et al., 2019). 
Table 5. Stomatal conductance in peanut plants as a function of electrical conductivities of the irrigation water (EC) and organo-mineral fertilizers, at 40 and 54 DAS.

\begin{tabular}{|c|c|c|c|c|}
\hline \multirow{3}{*}{ Fertilization } & \multicolumn{4}{|c|}{ Stomatal conductance - gs $\left(\mathrm{mol} \mathrm{m}^{-2} \mathrm{~s}^{-1}\right)$} \\
\hline & \multicolumn{2}{|c|}{40 DAS } & \multicolumn{2}{|c|}{$54 \mathrm{DAS}$} \\
\hline & $1.0 \mathrm{dS} \mathrm{m}^{-1}$ & $5.0 \mathrm{dS} \mathrm{m}^{-1}$ & $1.0 \mathrm{dS} \mathrm{m}^{-1}$ & $5.0 \mathrm{dS} \mathrm{m}^{-1}$ \\
\hline F1 - NPK $100 \%$ & $0.28 \mathrm{aA}$ & $0.04 \mathrm{bB}$ & $0.25 \mathrm{aA}$ & $0.15 \mathrm{bB}$ \\
\hline F2 - Biofertilizer $100 \%$ & $0.26 \mathrm{aA}$ & $0.13 \mathrm{bA}$ & $0.17 \mathrm{aB}$ & $0.13 \mathrm{aB}$ \\
\hline F3 - Plant ash $100 \%$ & $0.24 \mathrm{aA}$ & $0.10 \mathrm{bA}$ & $0.34 \mathrm{aA}$ & $0.23 \mathrm{aA}$ \\
\hline F4 - NPK $50 \%+$ Bio $50 \%$ & $0.28 \mathrm{aA}$ & $0.11 \mathrm{bA}$ & $0.48 \mathrm{aA}$ & $0.31 \mathrm{aA}$ \\
\hline F5 - NPK $50 \%+$ Ash $50 \%$ & $0.49 \mathrm{aA}$ & $0.06 \mathrm{bB}$ & $0.33 \mathrm{aA}$ & $0.13 \mathrm{bB}$ \\
\hline MSD column & \multicolumn{2}{|c|}{0.09} & \multicolumn{2}{|c|}{0.04} \\
\hline MSD line & \multicolumn{2}{|c|}{0.13} & \multicolumn{2}{|c|}{0.06} \\
\hline
\end{tabular}

$\mathrm{MSD}=$ minimum significant difference. DAS $=$ days after sowing. ${ }^{*}$ Means followed by the same lowercase letter in the rows, or uppercase letter in the columns, are not statistically different from each other by the Tukey's test at 5\% probability level.

The stomatal conductance of plants irrigated with brackish water presented significant differences at $54 \mathrm{DAS}$, with lower stomatal opening than those irrigated with fresh water, regardless of the fertilizer used (Table 5). The high salt concentration combined with the fertilizers in F1, F2, and F5, resulted in the lowest stomatal openings. This negative effect may be related to the high salt contents of the fertilizers used, which decreases water absorption and, consequently, the stomatal conductance (VIANA et al., 2013).

Different results for the use of bovine manure -based biofertilizer combined with irrigation with brackish water were found by Sousa et al. (2018) for soybean, and by Sousa et al. (2020), for okra crops, who found that this organic input attenuates salt stress and promotes stomatal opening.

The mean photosynthetic rates found for the different fertilizers and salinity levels at 40 and 54 DAS are shown in Table 6. The fertilizers showed significantly different photosynthetic rates at 40 DAS in both salinity levels, with the highest means for the fresh water, when using F1, F2, and F5. These fertilizers may have contributed to a better nutritional balance, and higher physiological and biochemical activities, since nitrogen promotes a better structural composition, and is a component of enzymes and chlorophylls; whereas $\mathrm{K}^{+}$is part of activation enzymes related to respiration and photosynthetic rate (TAIZ et al., 2017; SOUZA et al., 2018).

Increases in salt concentration decrease stomatal conductance and, consequently, $\mathrm{CO}_{2}$ assimilation and transpiration, which damages the photochemical system due to excess light energy in the photosystem II (FREIRE et al., 2014). These were similar results to those reported by Bezerra et al. (2018), who evaluated physiological indexes of guava plants (Paluma cultivar) grown under irrigation with brackish water and fertigation with nitrogen and found decreases in photosynthetic rates as the salt stress was increased.

Despite the decrease in photosynthetic rate as the salinity was increased, F2 and F4 had higher effects than the other treatments when using brackish water. According to Souza et al. (2019), the release of humic substances by use of bovine manure-based biofertilizer in saline environments decreases the deleterious effects of salts. Sousa et al. (2018) also found higher photosynthetic rates in soybean plants when applying bovine manure-based biofertilizer in a saline environment.

The treatments irrigated with fresh water (EC $1.0 \mathrm{dS} \mathrm{m} \mathrm{m}^{-1}$ ) were statistically superior to those irrigated with brackish water $\left(5.0 \mathrm{dS} \mathrm{m}^{-1}\right)$ at $54 \mathrm{DAS}$, regardless of the fertilizer used. This result can be related to a nutritional imbalance caused by excess $\mathrm{Na}^{+}$and $\mathrm{Cl}^{-}$, which caused absorption losses of $\mathrm{K}^{+}$, $\mathrm{Ca}^{2+}, \mathrm{Mg}^{2+}, \mathrm{NO}_{3}^{-}$, and $\mathrm{H}_{2} \mathrm{PO}_{4}^{-}$ions (SÁ et al., 2019). This deficiency harms the transport and assimilation of essential nutrients for the osmotic adjustment to salinity, such as $\mathrm{N}$ and $\mathrm{K}^{+}$(SILVA et al., 2019).

Costa et al. (2019) found similar results for zucchini crops, with higher photosynthetic rates for treatments with fertilizer application when irrigated with low-salinity water; they also reported that the high quantity of $\mathrm{K}^{+}$in the plant ash is essential for photochemical processes of plants, such as enzymatic activation, proteins synthesis, cell extension, osmoregulation, and opening and closure of stomata. 
Table 6. Photosynthetic rates of peanut plants as a function of electrical conductivities of the irrigation water (EC) and organo-mineral fertilizers at 40 and 54 DAS.

\begin{tabular}{|c|c|c|c|c|}
\hline \multirow{3}{*}{ Fertilization } & \multicolumn{4}{|c|}{ Photosynthetic rates $-A\left(\mu \mathrm{mol} \mathrm{m}{ }^{2} \mathrm{~s}^{-1}\right)$} \\
\hline & \multicolumn{2}{|c|}{40 DAS } & \multicolumn{2}{|c|}{54 DAS } \\
\hline & $1.0 \mathrm{dS} \mathrm{m}^{-1}$ & $5.0 \mathrm{dS} \mathrm{m}^{-1}$ & $1.0 \mathrm{dS} \mathrm{m}^{-1}$ & $5.0 \mathrm{dS} \mathrm{m}^{-1}$ \\
\hline F1 - NPK 100\% & $8.89 \mathrm{aAB}$ & $3.89 \mathrm{bC}$ & $10.25 \mathrm{aA}$ & $6.01 \mathrm{bB}$ \\
\hline F2 - Biofertilizer $100 \%$ & $8.60 \mathrm{aAB}$ & $10.48 \mathrm{aA}$ & $7.60 \mathrm{aA}$ & $4.47 \mathrm{bB}$ \\
\hline F3 - Plant ash $100 \%$ & $8.08 \mathrm{aB}$ & $7.02 \mathrm{aB}$ & $12.24 \mathrm{aA}$ & $7.62 \mathrm{bA}$ \\
\hline F4 - NPK 50\% + Bio 50\% & $8.51 \mathrm{aB}$ & $7.62 \mathrm{aAB}$ & $12.52 \mathrm{aA}$ & $8.67 \mathrm{bA}$ \\
\hline F5 - NPK $50 \%+$ Ash $50 \%$ & $11.88 \mathrm{aA}$ & $6.00 \mathrm{bC}$ & $12.38 \mathrm{aA}$ & $3.72 \mathrm{bC}$ \\
\hline MSD column & \multicolumn{2}{|c|}{2.32} & \multicolumn{2}{|c|}{1.66} \\
\hline MSD line & \multicolumn{2}{|c|}{3.29} & \multicolumn{2}{|c|}{2.38} \\
\hline
\end{tabular}

MSD = minimum significant difference. DAS = days after sowing. $* *$ Means followed by the same lowercase letter in the rows, or uppercase letter in the columns, are not statistically different from each other by the Tukey's test at $5 \%$ probability level.

The mean transpiration found for the different fertilizers and salinity levels, at 40 and 54 DAS, are shown in Table 7 . These results denote that fertilizer applications had no significant effect on transpiration at 40 DAS, when using irrigation with fresh water. However, plant under F1, F3, and F5 showed decreases in transpiration rate as the water salinity was increased. This partial decrease in transpiration at 40 DAS can be attributed to the plant stomatal closure to decrease absorption of toxic ions, such as $\mathrm{Cl}^{-}$and $\mathrm{Na}^{+}$(SOUZA et al., 2019; LIMA et al., 2020).

However, the peanut plants presented the highest transpiration rates when using the F2 fertilizer and irrigation with brackish water, at 40 DAS. This result denotes that the bovine manurebased biofertilizer decreased the stress effect caused by the irrigation with brackish water at 40 DAS. The chemical composition of the bovine manure-based biofertilizer presented essential nutrients, such as $\mathrm{Ca}^{2+}, \mathrm{N}$ and $\mathrm{K}^{+}$, which probably increased the $\mathrm{K} / \mathrm{Na}$ and $\mathrm{Ca} / \mathrm{Na}$ ratios (VIANA et al., 2013). Sousa et al. (2020) found similar results for okra plants, with decreases in transpiration as the salinity of the irrigation water was increased. However, the deleterious effects were mitigated when using bovine manure-based biofertilizer.

The transpiration decreased as the salt concentration in the irrigation water was increased at 54 DAS, except for F4 (Table 7). Plants in the treatments F1 and F5 presented the lowest transpiration rates when irrigated with brackish water. The use of mineral potassium $(\mathrm{KCl})$ may have increased the salinity level of the brackish water, decreasing the soil osmotic potential and the absorption of water by the plants (LIMA et al., 2020).

Prazares et al. (2015) reported similar results when evaluating the growth and gas exchange of cowpea plants grown under irrigation with brackish water and application of potassium rates; they found that the use of $200 \%$ of the recommended rate of $\mathrm{KCl}$ and irrigation with brackish water $\left(5.0 \mathrm{dS} \mathrm{m}^{-1}\right)$ decreased the transpiration rates.

The increases in transpiration at 54 DAS in both salinity levels may be a plant strategy to regulate the cell water potential and adapt to the unfavorable environmental conditions (SÁ et al., 2019). In addition, the pod formation process starts at this phenological stage, requiring a high photosynthetic rate and transpiration to produce carbohydrates that will be distributed to the plant reproduction parts (TAIZ et al., 2017).

The leaf temperature was statistically higher when using brackish water at 40 DAS, regardless of the fertilizer used (Table 8). The interaction between transpiration and leaf temperature is one of the main physiological mechanisms responsible to maintain the leaf temperature within the ideal limit. According to Simões et al. (2018), high leaf temperatures can cause stomatal closure and decreases in photosynthetic rate and enzymatic activity, causing enzymatic denaturation. 
Table 7. Transpiration of peanut plants as a function of electrical conductivities of the irrigation water (EC) and organomineral fertilizers at 40 and 54 DAS.

\begin{tabular}{|c|c|c|c|c|}
\hline \multirow{3}{*}{ Fertilization } & \multicolumn{4}{|c|}{ Transpiration - E $\left(\mathrm{mol} \mathrm{m}^{-2} \mathrm{~s}^{-1}\right)$} \\
\hline & \multicolumn{2}{|c|}{40 DAS } & \multicolumn{2}{|c|}{$54 \mathrm{DAS}$} \\
\hline & $1.0 \mathrm{dS} \mathrm{m}^{-1}$ & $5.0 \mathrm{dS} \mathrm{m}^{-1}$ & $1.0 \mathrm{dS} \mathrm{m}^{-1}$ & $5.0 \mathrm{dS} \mathrm{m}^{-1}$ \\
\hline F1 - NPK 100\% & $1.80 \mathrm{aA}$ & $0.75 \mathrm{bB}$ & $2.60 \mathrm{aA}$ & $1.93 \mathrm{bB}$ \\
\hline F2 - Biofertilizer $100 \%$ & $2.06 \mathrm{aA}$ & $1.58 \mathrm{aA}$ & $2.14 \mathrm{aA}$ & $2.26 \mathrm{aB}$ \\
\hline F3 - Plant ash $100 \%$ & $1.85 \mathrm{aA}$ & $1.35 \mathrm{bA}$ & $2.85 \mathrm{aA}$ & $2.41 \mathrm{bA}$ \\
\hline F4 - NPK $50 \%+$ Bio $50 \%$ & $1.74 \mathrm{aA}$ & $1.42 \mathrm{aA}$ & $3.24 \mathrm{aA}$ & $2.75 \mathrm{bA}$ \\
\hline F5 - NPK 50\% + Ash 50\% & $2.12 \mathrm{aA}$ & $1.10 \mathrm{bA}$ & $2.56 \mathrm{aA}$ & $1.39 \mathrm{bB}$ \\
\hline MSD column & \multicolumn{2}{|c|}{0.38} & \multicolumn{2}{|c|}{0.30} \\
\hline MSD line & \multicolumn{2}{|c|}{0.54} & \multicolumn{2}{|c|}{0.43} \\
\hline
\end{tabular}

MSD $=$ minimum significant difference. DAS $=$ days after sowing. $* *$ Means followed by the same lowercase letter in the rows, or uppercase letter in the columns, are not statistically different from each other by the Tukey's test at $5 \%$ probability level.

Table 8. Leaf temperature of peanut plants as a function of electrical conductivities of the irrigation water (EC) and organomineral fertilizers at 40 and 54 DAS.

\begin{tabular}{|c|c|c|c|c|}
\hline \multirow{3}{*}{ Fertilization } & \multicolumn{4}{|c|}{ Leaf temperature - LT $\left({ }^{\circ} \mathrm{C}\right)$} \\
\hline & \multicolumn{2}{|c|}{40 DAS } & \multicolumn{2}{|c|}{54 DAS } \\
\hline & $1.0 \mathrm{dS} \mathrm{m}^{-1}$ & $5.0 \mathrm{dS} \mathrm{m}^{-1}$ & $1.0 \mathrm{dS} \mathrm{m}^{-1}$ & $5.0 \mathrm{dS} \mathrm{m}^{-1}$ \\
\hline F1 - NPK 100\% & $28.47 \mathrm{bB}$ & $31.35 \mathrm{aA}$ & $29.82 \mathrm{bB}$ & $30.62 \mathrm{aA}$ \\
\hline F2 - Biofertilizer $100 \%$ & $29.03 \mathrm{bAB}$ & $30.16 \mathrm{aB}$ & $30.70 \mathrm{aA}$ & $30.15 \mathrm{aA}$ \\
\hline F3 - Plant ash $100 \%$ & $29.36 \mathrm{bA}$ & $30.56 \mathrm{aB}$ & $29.85 \mathrm{bB}$ & $30.32 \mathrm{aA}$ \\
\hline F4 - NPK $50 \%+$ Bio $50 \%$ & $27.80 \mathrm{bC}$ & $30.65 \mathrm{aB}$ & $29.72 \mathrm{bB}$ & $30.02 \mathrm{aA}$ \\
\hline F5 - NPK $50 \%+$ Ash $50 \%$ & $27.06 \mathrm{bC}$ & $31.43 \mathrm{aA}$ & $29.92 \mathrm{aB}$ & $30.55 \mathrm{aA}$ \\
\hline MSD column & \multicolumn{2}{|c|}{0.44} & \multicolumn{2}{|c|}{0.55} \\
\hline MSD line & \multicolumn{2}{|c|}{0.63} & \multicolumn{2}{|c|}{0.78} \\
\hline
\end{tabular}

MSD = minimum significant difference. DAS = days after sowing. **Means followed by the same lowercase letter in the rows, or uppercase letter in the columns, are not statistically different from each other by the Tukey's test at $5 \%$ probability level.

The means of leaf temperature at 54 DAS were lower when using brackish water, except for F2. The stomatal closure caused by the salt stress decreases the transpiration and increases leaf temperature (FIGUEIREDO et al., 2019). Contrastingly, Sousa et al. (2012) found no effect of phosphate fertilizer on the leaf temperature of Jatropha curcas L. as the electrical conductivity of the irrigation water was increased.
The means of water use efficiency at 40 DAS in F2 were higher when using brackish water (Table 9). Silva et al. (2019) reported that decreases in water availability caused by changes in the soil osmotic potential had a natural trend to decrease transpiration flow and activate the osmotic adjustment mechanisms to ensure water absorption and maintain cell turgidity. In addition, biofertilizers have microorganisms that increase the amounts of 
antioxidant enzymes, which induce the removal of salts from roots, promoting the osmotic adjustment and improving plant protection against salt stress (BABAEI et al., 2017).

Table 9. Water use efficiency of peanut plants as a function of electrical conductivities of the irrigation water (EC) and organo-mineral fertilizers at 40 and 54 DAS.

\begin{tabular}{|c|c|c|c|c|}
\hline \multirow{3}{*}{ Fertilization } & \multicolumn{4}{|c|}{ Water use efficiency - WUE $\left.\left(\left[\mu \mathrm{mol} \mathrm{m}^{-2} \mathrm{~s}^{-1}\right)\left(\mathrm{mol} \mathrm{H}_{2} \mathrm{O} \mathrm{m}^{-2} \mathrm{~s}^{-1}\right)^{-1}\right]\right)$} \\
\hline & \multicolumn{2}{|c|}{40 DAS } & \multicolumn{2}{|c|}{$54 \mathrm{DAS}$} \\
\hline & $1.0 \mathrm{dS} \mathrm{m}^{-1}$ & $5.0 \mathrm{dS} \mathrm{m}^{-1}$ & $1.0 \mathrm{dS} \mathrm{m}^{-1}$ & $5.0 \mathrm{dS} \mathrm{m}^{-1}$ \\
\hline F1 - NPK 100\% & $4.89 \mathrm{aAB}$ & $5.33 \mathrm{aB}$ & $3.96 \mathrm{aB}$ & $3.11 \mathrm{bA}$ \\
\hline F2 - Biofertilizer $100 \%$ & $4.15 \mathrm{bB}$ & $6.71 \mathrm{aA}$ & $3.52 \mathrm{aB}$ & $1.97 \mathrm{bB}$ \\
\hline F3 - Plant ash $100 \%$ & $4.41 \mathrm{aAB}$ & $5.22 \mathrm{aB}$ & $4.29 \mathrm{aAB}$ & $3.12 \mathrm{aB}$ \\
\hline F4 - NPK $50 \%+$ Bio $50 \%$ & $4.90 \mathrm{aAB}$ & $5.35 \mathrm{aB}$ & $4.87 \mathrm{aA}$ & $3.15 \mathrm{aA}$ \\
\hline F5 - NPK $50 \%+$ Ash $50 \%$ & $5.58 \mathrm{aA}$ & $5.45 \mathrm{aAB}$ & $3.87 \mathrm{aB}$ & $2.73 \mathrm{bAB}$ \\
\hline MSD column & \multicolumn{2}{|c|}{0.94} & \multicolumn{2}{|c|}{0.56} \\
\hline MSD line & \multicolumn{2}{|c|}{1.34} & \multicolumn{2}{|c|}{0.79} \\
\hline
\end{tabular}

MSD = minimum significant difference. DAS = days after sowing. **Means followed by the same lowercase letter in the rows, or uppercase letter in the columns, are not statistically different from each other by the Tukey's test at $5 \%$ probability level.

The means of water use efficiencies found at 54 DAS for F3 and F4 were higher when irrigated with fresh water (Table 9). The mineral composition of these fertilizers produces chelate compounds from the biological activity, which are enzymatic activators in the plant metabolism (CHAGAS et al., 2018). The photosynthetic rates and transpirations found may also have contributed to these results; the organic fertilizer and the combination of organic and mineral fertilizers resulted in higher means for these variables.

The water use efficiency decreased from 40 to 54 DAS when using brackish water. However, this decrease was more affected by the age of the plants than by the treatments used (Table 9). This was also found by Cova et al. (2020) for noni plants irrigated with brackish waters.

The means of chlorophyll index (SPAD) of plants in F2 presented statistical differences for the irrigation waters at 54 DAS (Table 10). Costa et al. (2019) evaluated irrigations with brackish water and applications of soil fertilizers in zucchini crops and found decreases in the SPAD index when the plants were fertilized with plant ash and irrigated with brackish water $\left(2.5 \mathrm{dS} \mathrm{m}^{-1}\right)$.

Table 10. Chlorophyll index of peanut plants as a function of electrical conductivities of the irrigation water (EC) and organo-mineral fertilizers at 54 DAS.

\begin{tabular}{ccc}
\hline & \multicolumn{2}{c}{ Chlorophyll index - SPAD } \\
\cline { 2 - 3 } Fertilization & \multicolumn{2}{c}{54 DAS } \\
\cline { 2 - 3 } & $1.0 \mathrm{dS} \mathrm{m}^{-1}$ & $5.0 \mathrm{dS} \mathrm{m}^{-1}$ \\
\hline F1 - NPK 100\% & $37.60 \mathrm{aA}$ & $41.95 \mathrm{aA}$ \\
F2 - Biofertilizer 100\% & $29.62 \mathrm{bA}$ & $28.22 \mathrm{aB}$ \\
F3 - Plant ash 100\% & $32.43 \mathrm{aA}$ & $32.95 \mathrm{aAB}$ \\
F4 - NPK 50\% + Bio 50\% & $31.35 \mathrm{aA}$ & $36.40 \mathrm{aAB}$ \\
F5 - NPK 50\% + Ash 50\% & $34.06 \mathrm{aA}$ & \\
\hline MSD column & & 6.87 \\
MSD line & & 9.77 \\
\hline
\end{tabular}

MSD $=$ minimum significant difference. DAS $=$ days after sowing. $* *$ Means followed by the same lowercase letter in the rows, or uppercase letter in the columns, are not statistically different from each other by the Tukey's test at $5 \%$ probability level. 
However, plants in F2 irrigated with brackish water $\left(5.0 \mathrm{dS} \mathrm{m}^{-1}\right)$ had higher chlorophyll index (41.95 SPAD index). This result is probably related to the better distribution of $\mathrm{N}$ and $\mathrm{Mg}$ of the biofertilizer in the substrate, making large amounts of these nutrients to be absorbed by roots and distributed to the plant parts through the xylem (SOUZA et al., 2019; COSTA et al., 2019). In addition, the relative chlorophyll content is related to the total leaf $\mathrm{N}$ contents, which are part of enzymes associated with chloroplasts (TAIZ et al., 2017). Different results were found by Freire et al. (2013), who reported decreases in chlorophyll contents when using a biofertilizer in passion fruit plants irrigated with brackish water.

\section{CONCLUSIONS}

Plants irrigated with fresh water $\left(1.0 \mathrm{dS} \mathrm{m}^{-1}\right)$ presented higher stomatal conductance and photosynthetic and transpiration rates, regardless of the fertilizer used.

The treatment with $100 \%$ bovine manurebased biofertilizer mitigated the salt stress and increased water use efficiency at 40 days after sowing (DAS) and decreased leaf temperature, resulting in a high relative chlorophyll content at 54 DAS.

The salt stress caused by using brackish water $\left(5.0 \mathrm{dS} \mathrm{m}^{-1}\right)$ increased the leaf temperature of peanut plants, regardless of the fertilizer used, except when using only $100 \%$ bovine manure-based biofertilizer at 54 DAS.

\section{ACKNOWLEDGEMENTS}

The authors thank the Foundation of Support for Scientific and Technological Development of the State of Ceará (FUNCAP) for the financial support for this research.

\section{REFERENCES}

ALBUQUERQUE, A. S.; SANTOS, R. V.; FONSÊCA, N. C. Atributos químicos de um solo salino sob efeito de composto organomineral. Revista Ambientale, 10: 10-17, 2018.

BABAEI, K. et al. Effects of bio fertilizer and nano $\mathrm{Zn}-\mathrm{Fe}$ oxide on physiological traits, antioxidant enzymes activity and yield of wheat (Triticum aestivum L.) under salinity stress. Journal of Plant Interactions, 12: 381-389, 2017.

BARBOSA, R. M.; HOMEM, B. F. M.; TARSITANO, M. A. A. Custo de produção e lucratividade da cultura do amendoim no município de Jaboticabal. São Paulo. Revista Ceres, 61: 475$481,2014$.

BERNARDO, S. et al. Manual de irrigação. 9. ed. Viçosa, MG: Editora UFV, 2019. 545 p.

BEZERRA, I. L. et al. Physiological indices and growth of 'paluma'guava under saline water irrigation and nitrogen fertigation. Revista Caatinga, 31: 808-816, 2018.

CARVALHO, L. L. S. et al. Caracterização dos usos das águas subterrâneas no perímetro irrigado do baixo Acaraú-CE. Revista em Agronegócio e Meio Ambiente, 13: 601-620, 2020.

CHAGAS, K. L. et al. Agronomic performance of strawberry plants under growing environments and organomineral fertilization. Pesquisa Agropecuária Tropical, 48: 331-339, 2018.

COSTA, F. H. R. et al. Água salina e formas de adubação na cultura da abobrinha. Revista brasileira de agricultura irrigada-RBAI, 13: 3757 3764, 2019.

COVA, A. M. W. et al. Physiological and biochemical responses and fruit production of noni (Morinda citrifolia L.) plants irrigated with brackish water. Scientia Horticulturae, 260: 1-11, 2020.

DIAS, A. S. et al. Physiological indices and production of sesame under salt stress and nitrate/ ammonium proportions. Bioscience Journal, 33: 610-620, 2017.

FERNANDES, V. L. B. Recomendações de adubação e calagem para o estado do Ceará. Fortaleza, CE: Imprensa Universitária, 1993. 248 p.

FIGUEIREDO, F. R. A. et al. Respostas fisiológicas de mulungu submetida a estresse salino e aplicação de ácido salicílico. Irriga, 24: 662-675, 2019.

FREIRE, J. L. O. et al. Rendimento quântico e trocas gasosas em maracujazeiro amarelo sob salinidade hídrica biofertilização e cobertura morta. Revista Ciência Agronômica, 45: 82-91, 2014.

FREIRE, J. L. O. et al. Teores de clorofila e composição mineral foliar do maracujazeiro irrigado com águas salinas e biofertilizante. Revista de Ciências Agrárias, 36: 57-70, 2013.

KÖPPEN, W. P. Die klimate der erde: Grundriss der klimakunde. Berlin: Walter de Gruyter \& So. $1923.369 \mathrm{p}$

LIMA, G. S. D. et al. Gas exchange. chloroplast 
pigments and growth of passion fruit cultivated with saline water and potassium fertilization. Revista Caatinga, 33: 184-194, 2020.

MINHAS, P. S. et al. Coping with salinity in irrigated agriculture: Crop evapotranspiration and water management issues. Agricultural Water Management. 227: 1-22, 2020.

PRAZERES, S. S. et al. Crescimento e trocas gasosas de plantas de feijão-caupi sob irrigação salina e doses de potássio. Revista Agro@mbiente On-line, 9: 111-118, 2015.

RHOADES, J. D.; KANDIAH, A.; MASHALI, A. $M$. Uso de águas salinas para produção agrícola. 1. ed. Campo Grande, PB: UFPB, 2000. 117 p. (Estudos FAO. Irrigação e Drenagem, 48).

RODRIGUES, V. D. S. et al. Yield of maize crop irrigated with saline waters. Revista Brasileira de Engenharia Agrícola e Ambiental, 24: 101-105, 2020 .

SÁ, F. V. S. et al. Ecophysiology of west indian cherry irrigated with saline water under phosphorus and nitrogen doses. Bioscience Journal, 35: 211$221,2019$.

SILVA, F. A. S.; AZEVEDO, C. A. V. The Assistat Software Version 7.7 and its use in the analysis of experimental data. African Journal of Agricultural Research, 11: 3733-3740, 2016.

SILVA, S. S. D. et al. Gas exchanges and production of watermelon plant under salinity management and nitrogen fertilization. Pesquisa Agropecuária Tropical, 49: 1-10, 2019.

SIMÕES. W. L. et al. Morphophysiological and productive responses of sunflower varieties to irrigation. Revista Caatinga, 31: 143-150, 2018.

SOUSA, A. E. C. et al. Teores de nutrientes foliares e respostas fisiológicas em pinhão manso submetido a estresse salino e adubação fosfatada. Revista Caatinga, 25: 144-152, 2012.

SOUSA, G. G. et al. Irrigation with saline water in soybean (Glycine $\max$ (L.) Merr.) in a soil with bovine biofertilizer. Revista Brasileira de Engenharia Agrícola e Ambiental, 22: 604-609. 2018.

SOUSA, G. G. et al. Morphophysiological characteristics of okra plants submitted to saline stress in soil with organic fertilizer. Comunicata Scientiae, 11: 1-8, 2020.
SOUZA, J. T. et al. Effects of water salinity and organomineral fertilization on leaf composition and production in Passiflora edulis. Revista Brasileira de Engenharia Agrícola e Ambiental, 22: 535-540, 2018

SOUZA, M. V. P. et al. Saline water and biofertilizer from bovine and goat manure in the Lima bean crop. Revista Brasileira de Ciências Agrárias, 14: 1-8, 2019

TAIZ, L. et al. Fisiologia e Desenvolvimento Vegetal. 6. ed. Porto Alegre, RS: Artmed, 2017. 888 p.

VIANA, T. V. A. et al. Trocas gasosas e teores foliares de NPK em meloeiro adubado com biofertilizantes. Revista Brasileira de Ciências Agrárias, 8: 595-601, 2013. 